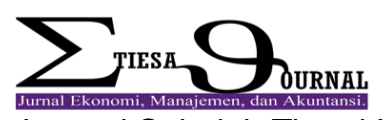

Journal Sekolah Tinggi IImu Ekonomi Saumalki

\section{Manajemen Pengelolaan Dana Desa di Desa Ilnge Studi Kasus Penanganan Covid-19}

\author{
Rendy Oratmangun \\ Sekolah Tinggi Ilmu Ekonomi Saumlaki \\ oratmangunr@gmail.com
}

Abstrak

Covid-19 adalah masalah global yang harus dihadapi, tidak terkecuali di Kabupaten Kepulauan Tanimbar terlebih khusus Desa Ilnge. Permasalahan ini menyebabkan restrukturisasi anggaran secara besar-besaran dan akibatnya pengelolaan dana yang besar ini mengalami permasalahan. Dalam penelitian ini peneliti menggunakan metode kualitatif untuk menjelaskan secara terperinci bagaimana manajemen pengelolaan dana desa yang dialihkan untuk penanganan Covid-19 di Desa Ilnge dengan tahapan triangulasi data. Dengan hasil, pertama perencanaan dana desa dalam pencegahan dan penanggulangan Covid-19 di desa Ilngei dilakukan bersama dengan melibatkan masyarakat tetapi dalam bentuk perwakilan yang diwakilkan. Kedua, dalam proses perencanaan dana desa untuk penanggulangan Covid-19, tetapi pemerintah desa Ilngei lebih dominan dalam menentukan kebijakan penggunaan dana. Ketiga, Hasil perencanaan yang dilakukan ditetapkan dengan baik dan sesuai akan tetapi masyarakat masih mengeluh terhadap implementasi hasil perencanaan. Keempat, Pemerintah telah berupaya semaksimal mungkin untuk menjawab setiap keluhan dan seluruh aspirasi masyarakat selama pandemi Covid-19 berlangsung namun pemerintah pun terbatas secara keuangan, dengan jumlah dana tersebut Rp. 558.697.500.

Kata Kunci: Lock-Down, Perencanaan, Pengelolaan, Pelaksanaan, Pengontrolan

\section{Pendahuluan}

Pada akhir tahun 2019 yakni dibulan Desember dunia dikejutkan dengan sebuah fenomena memprihatinkan serta menimbulkan kekhawatiran, dengan adanya virus mematikan yang pertama kali muncul di kota Wuhan, Provinsi Hubei. Fenomena ini terjadi pada sebuah pasar ikan di Wuhan tepatnya tanggal 18 Desember hingga 29 Desember 2019. Awalnya daerah Wuhan yang terinveksi namun akibat media dan cara penularan yang cepat sehingga penyebaran virus tersebut meningkat hingga memuncak dengan menyerang seluruh manusia di daerah Wuhan. Virus tersebut tidak lain ialah Covid-19 (Tim Penanganan Kasus pasien dengan Penyakit Infeksi New Emerging dan Re-emerging Disease (dr. Cipto Mangunkusumo).

Dari beberapa pasien yang diteliti menunjukkan adanya virus jenis baru yang belum pernah ada. Awalnya, pasien dengan status positif tertular Covid-19 dinamakan sementara sebagai 2019 novel corona virus (2019-nCoV), kemudian badan Kesehatan Dunia (WHO mengumumkan nama baru pada 11 Februari 2020 yaitu Coronavirus Disease (Covid-19) yang disebabkan oleh virus Severe Acute Respiratory Syndrome Coronavirus-2 (SARS-CoV-2). Virus ini dapat ditularkan dari manusia ke manusia dan telah menyebar secara luas dari Wuhan menyelimuti China dan lebih dari 190 negara di dunia. Selanjutnya pada tanggal 12 Maret 2020, WHO mengumumkan Covid-19 sebagai pandemik. Hingga tanggal 29 Maret 2020 tercatat terdapat 634.835 kasus dan 33.106 jumlah kematian akibat Covid-19 di seluruh dunia. Penyebaranya terus meningkat, dan berhasil menyebar hampir ke seluruh pelosok daerah di dunia.

Sementara di negara Indonesia untuk mempercepat penanganannya, Presiden Republik Indonesia mengeluarkan Kepres No. 7 tahun 2020 tentang Pembentukan Gugus Tugas Percepatan Penanganan Corona Virus Disease (Covid-19) menunjuk BNPB sebagai koordinator sehingga Kepala BNPB mempunyai kewenangan melaksanakan penyelenggaraan penanggulangan Bencana 
termasuk kemudahan akses dalam penanganan darurat benvana sampai batas waktu tertentu, dan telah sudah ditetapkan 33.076 pada awal bulan Juni tahun 2020 ditambah lagi dengan pernyataan Presiden RI akhir bulan Mei 2020 yang menyakatan secara resmi bahwa seluruh wilayah di Indonesia akan kembali normal setelah beberapa kali ada pada status Lockdowm, dan Pembatasan Sosial Berskala Besar (PSBB). Pandemik Covid-19 ini menyebabkan kerugian negara yang melampaui berbagai bidang dan memberikan dampak yang sangat memprihatinkan di bidang kesehatan dan keuangan. Namun kenyataan yang sangat disayangkan ialah pandemik Covid-19 sampai saat ini belum usai walaupun berbagai upaya telah dilakukan baik secara medis maupun secara sosial sedangkan disisi lain realitas bangsa yang kembali ada pada status New Normal atau kondisi normal dimana setiap masyarakat akan kembali beraktifitas tanpa ada batasan dan lain sebagainya.

Di Maluku, melalui pemerintah provinsi Maluku menetapkan 1 (satu) orang positif terinfeksi Covid-19 pada Minggu 22 Maret 2020. Data tersebut dirilis pemerintah provinsi Maluku berdasarkan hasil pemeriksaan pasien dalam pengawasan (PDP) yang dikirim oleh Balitbangkes Kementrian Kesehatan, disamping itu rillis data pasien positif Covid-19 pemerintah provinsi Maluku juga merilis data Orang dalam Pemantauan (ODP) dan PDP secara keseluruhan di provinsi Maluku, dan dari data tersebut 26 orang ditetapkan sebagai orang dalam Pemantauan (ODP) yang berasal dari Kabupaten Kepulauan Tanimbar dan termasuk data terbanyak dari 10 Kabupaten diprovinsi Maluku. Dalam situasi tersebut, Kabupaten Kepulauan Tanimbar melakukan langkah cepat dengan melakukan tracking terhadap seluruh orang yang masuk di Kabupaten Kepulauan Tanimbar baik melalui Pelabuhan Laut maupun Bandar Udara dan terdapat 28 ODP per tanggal 23 Maret 2020. Selain itu kondisi daerah Maluku yang juga terinfeski virus Covid-19. Jumlah kasus terus meningkat mencapai lebih dari 220 kasus positif terinfeksi virus Covid-19 (Maluku.com 6 Juni 2020).

Penyebaran Covid-19 mulai meningkat dan diawal bulan September tahun 2020 secara resmi ditetapkan bahwa daerah Kabupaten Kepulauan Tanimbar beranjak dari zona hijau menjadi Zona merah dengan jumlah kasusu terinfeksi Covid-19 mencapai 43 kasusu dan untuk penanganan secara tepat serta untuk menghindari penularan Covid-19 para pasien dikarantina dan dirawat. Disisi lain daerah harus berada pada konsisi normal. Pemerintah terus berupaya untuk menanggulangi pandemik Covid-19. Bahkan tidak dengan tanggung pemerintah pusat mendukung penanggulangan pandemik Covid-19 dengan dukungan pengganggaran dalam jumlah yang relatif tinggi. Pada prinsipnya pemerintah Indonesia mendukung segala upaya untuk menanggulangi pandemik Covid-19. Hal ini dibuktikan dengan dukungan yang diberikan oleh pemerintah lewat penyaluran berbagai bantuan teristimewa bantuan keuangan. Dalam Keputusan Presiden Republik Indonesia No. 11 Tahun 2020 Tentang Penetapan Kedaruratan Kesehatan Masyarakat Corona Virus Disease 2019 (Covid-19) yang didalamnya menjelaskan bahwa Corona Virus Disease 2019 Covid-I9 atau merupakan jenis penyakit yang menimbulkan Kedaruratan Kesehatan Masyarakat. Selain itu penetapkan Kedaruratan Kesehatan Masyarakat Corana Virus Disease 2019 (Covid-19) di Indonesia yang wajib dilakukan upaya penanggulangan. Dalam hal pengelolaan keuangan di desa tentunya akan terjadi pembengkakan anggaran dimana akan ada penambahan anggaran yang dikucurkan untuk membiayai upaya penanggulangan Covid-19, namun ada hal yang perlu diperhatikan yakni ketimpangan ekonomi yang terjadi antara wilyah di Maluku, terlebih khusus di Kabupaten Kepulauan Tanimbar yang mana banyak mengalami kesulitan saat pandemi ini melandah dunia saat ini, Malindar (2020) menyatakan bahwa dari 11 kabupaten kota, pembangunan ekonomi yang terjadi 
relatif Sangat berbeda jauh dengan pembangunan di pusat Provinsi (P.3)

Dukungan Keuangan dalam rangka menunjang penanggulangan Covid-19 tersebut disalurkan ke seluruh daerah bahkan pada level terendah yakni desa. Desa memiliki tanggung jawab untuk mengelola keuangan desa tersebut dengan baik dan maksimal dalam menanggulangi Covid-19 yang sedang dihadapi, apalagi Indonesia akan kembali berada pada kondisi normal sebagaimana himbauan yang disampaikan oleh presiden pada akhir bulan Mei yakni "Masyarakat perlu waspada dan tetap menjaga kondisi agar terhindar dari penyebaran virus Covid-19 serta akses antar daerah akan kembali normal pada tanggal 1 Juni 2020. Untuk menindaklanjuti kondisi New Normal tersebut desa harus sesegera mungkin membentuk Tim Relawan desa sebagaimana diatur dalam Surat Edaran No. 8 tahun 2020 tentang Desa Tanggap Covid-19 dan Penegasan Padat Karya Tunai Desa pada huruf (f) menyebutkan bahwa desa membentuk Relawan Desa Lawan Covid-19 dengan struktur yang melibatkkan Kepala desa dan seluruh Aparatur pemerintah desa, Tokoh Agama, Tokoh Adat Bidan Desa, dan lain sebagainya untuk sedapatnya menyikapi penyebaran virus Covid-19.

Kabupaten Kepulauan Tanimbar secara menyeluruh dan bahkan di setiap desa harus menyesuaikan dengan peraturan yang ada. Salah satu desa yang terdapat di Kabupaten Kepulauan Tanimbar Kecamatan Tanimbar Selatan yakni desa Ilngei juga perlu untuk menyesuaikan dengan konisi tersebut. Berdasarkan hasil observasi awal peneliti, yang dilakukan pada Hari Jumat, tanggal 29 Mei pukul 15.00 WIT, di depan pintu masuk desa Ilngei terdapat portal (Palang) yang dibuat di pintu masuk desa Ilngei. Portal (Palang) tersebut memiliki jadwal buka dan tutup yang diatur yakni pada pukul 06.00 WIT akan dibuka sampai pada pukul 20.00 WIT ditutup serta di tempat portal (Palang) tersebut terdapat masyarakat yang berjaga dengan menggunakan perlengkapan pelindung diri yang terbatas serta dilengkapi dengan fasilitas pengeras suara untuk menghimbau masyarakat menggunakan masker. Selain portal (Palang) tersebut dengan kondisi penjagaan yang cukup ketat, terdapat pula sistem penyemprotan yang dilakukan bagi setiap warga masyarakat beserta kendaraan yang melintas di pintu masuk tersebut.

Dengan kondisi demikian serta memperhatikan dari pola penyebaran virus Covid-19 sangatlah tidak tepat dan keliru karena metode pencegahan penyebaran virus Covid-19 bukan dengan membangun portal (Palang), sistem penyemprotan kendaraan dan lain sebagainya pada hal masyarakat yang berjaga pada portal (Palang) pun tidak mematuhi protokoler kesehatan dengan jarak minimal 1 meter, atau dengan kata lain keberadaan portal (Palang) sangat tidak menjamin terhadap pencegahan penyebaran virus Covid-19. Hal ini karena penyebaran virus Covid-19 terjadi melalui interaksi individu maupun kelompok dengan berbagai media penyebaran serta kontak dengan anggota tubuh seperti mata, hidung dan mulut serta penyebaranya yang sangat cepat. Dengan demikian apabila keuangan di desa (Dana Desa) dalam rangka penanggulangan Covid-19 dikelola untuk membangun portal (Palang), dan pos penjagaan dengan alasan pencegahan penyebaran Covid-19 keliru karena keberadaan portal (Palang) pada pintu masuk desa tidak menjamin Covid-19 tidak dapat menyebar.

Dari kenyataan dalam berbagai uraian yang telah dikemukakan pada latar belakang tersebut, maka peneliti merasa terdorong dengan kenyataan dan permasalahan yang ada untuk melakukan penelitian yang selanjutnya hasil penelitian akan dituangkan dalam bentuk tulisan ilmiah dengan judul "Manajemen Pengelolaan Dana Desa Di Desa Ilnge Studi Kasus Penanganan Covid-19”.

\section{Kajian Teori}

Menurut pendapat The Liang Gie dalam (Handoko:2001) menjelaskan bahwa administrasi keuangan merupakan "suatu konsep atau tata keuangan yang mencakup suatu proses, yaitu rangkaian kegiatan penataan 
yang berupa penyusunan anggaran belanja, penentuan sumber biaya, cara pemakaian, pembukuan, dan pertanggungjawaban atas pembiayaan yang dilakukan secara bersama untuk mencapai tujuan tertentu".

Sedangkan tujuan utama dari keseluruhan proses administrasi keuangan adalah pertanggung jawaban, efisiensi dan atau efektivitas dalam pengadaan dana serta dalam penggunaan dana yang diarahkan untuk mencapai tujuan organisasi. Selain itu administrasi keuangan menerapkan fungsifungsi pokok manajemen pada umumnya. Salah satu fungsi manajemen yang sederhana dan dapat diterapkan dalam administasi keuangan adalah fungsi manajemen yang dikemukakan oleh G. R. Terry dalam (Hasibuan Malayu, 2012) yaitu fungsi Planning (Perencanaan), Organizing (Pengorganisasian), Actuating (Penggerakan atau Pelaksanaan), Controlling (Pengawasan) atau yang biasa disebut dengan P.O.A.C. Fungsi menajemen ini perlu dan sangat penting untuk diterapkan pula dalam sistem manajemen keuangan, dimana keseluruhan keuangan dalam organisasi harus direncanakan, diorganisasikan, dikelolah atau digunakan, dikontrol secara baik. Secara sederhana apabila seluruh keuangan dilakukan dengan sistem manajemen yang baik dan sesuai tentu akan mempermudah pengelolaan, penggunaan dan pertanggungjawaban keuangan dan keuangan akan mampu memenuhi standar akuntabilitas keuangan.

Dalam pasal 71 ayat (1) Undangundang Nomor 6 Tahun 2014 tentang Desa menyatakan bahwa keuangan desa adalah "hak dan kewajiban desa yang dapat dinilai dengan uang serta segala sesuatu berupa uang dan barang yang berhubungan dengan pelaksanaan hak dan kewajiban desa." Selanjutnya pada ayat (2) mennyatakan bahwa adanya hak dan kewajiban akan menimbulkan pendapatan, belanja, pembiayaan, dan pengelolaan keuangan desa. Selain itu dalam undangundang yang sama, pada pasal 93 ayat (1) menyatakan bahwa "pengelolaan keuangan desa meliputi: perencanaan, penganggaran, pelaksanaan, penatausahaan, pelaporan, dan pertanggungjawaban”. Dengan merujuk pada ketentuan tersebut maka dapat diketahui bahwa mekanisme pengelolaan keuangan di desa merupakan serangkaian proses yang panjang dan berkesinambungan. Proses tersebut mengandung banyak mekanisme dan keberhasilan pengelolaan anggaran dana desa juga ditentukan oleh keseluruhan proses tersebut. Demikian halnya dengan pengelolaan dana desa dalam menanggulangi penyebaran Covid-19, pengelolaan haruh melalui mekanisme yang sama terhadap itu maka seluruh mekanismen mulai dari perencanaan, penganggaran, pelaksanaan, penatausahaan, pelaporan, sampai pada pertanggungjawaban penggunaan anggaran juga dilakukan dengan panduan pengelolaan sebagaimana dalam ketentuan yang berlaku. Keseluruhan proses pengelolaan keuangan desa tersebut dapat dijabarkan dalam diagram sebagai berikut:

Gambar 1: Siklus pengeloaan keuangan desa.

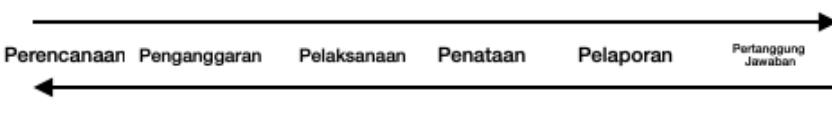

\section{Metode Penelitian}

Sesuai dengan tujuan penelitian yang telah diuraikan sebelumnya, maka pendekatan yang digunakan dalam penelitian ini adalah pendekatan penelitian kualitatif. Sedangkan jenis penelitian yang digunakan dalam rancangan penelitian ini adalah "deskriptif kualitatif', dimana data yang diperoleh dari lapangan dideskripsikan kemudian data tersebut dihubungkan dengan hasil wawancara yang dilakukan sehingga memberikan penjelasan terhadap temuan data penelitian, dan selanjutnya temuan data penelitian dianalisis berdasarkan teknik analisis data kualitatif dan kemudian mendapatkan kesimpulan sebagai jawaban yang jelas dan akurat demi mengungkap dan menerangkan permasalahan yang menjadi kesenjangan dalam penelitian. (Moleong, dalam Sujarweni, V. Wiratna 2014). Penelitian kualitatif merupakan salah satu prosedur penelitian yang 
menghasilkan data deskriptif berupa ucapan atau tulisan dan perilaku orang-orang yang diamati (Bogdan dan Taylor : 1992).

Pemilihan lokasi untuk melakukan penelitian tidak dapat ditentukan sesuai kemaunan belaka tetapi didasarkan pada realitas permasalahan yang terjadi pada lokasi. Yang menjadi lokasi atau lapangan dalam penelitian ini adalah Desa Ilngei Kecamatan Tanimbar Selatan, Kabupaten Kepulauan Tanimbar. Lokasi tersebut dipilih berdasarkan pertimbangan berikut:

1. Desa Ilngei, Kecamatan Tanimbar Selatan, Kabupan Kepulauan Tanimbar, merupakan lokasi penelitian yang sesuai dengan permasalahan penelitian yang diajukan,

2. Pemerintah dan Masyarakat Desa Ilngei, Kecamatan Tanimbar Selatan, Kabupaten Kepulauan Tanimbar, merupakan pihak yang paling mengetahui tentang kondisi dan atau keadaan terkait dengan manajemen pengelolaan dana desa serta proses penyerapan Anggaran Pendapatan Dan Belanja Desa (APBdes).

3. Desa Ilngei, Kecamatan Tanimbar Selatan, Kabupan Kepulauan Tanimbar. dapat dijangkau baik dari segi waktu, biaya serta ketersediaan data yang mudah diperoleh.

Penelitian yang dilakukan telah direncanakan bahkan sejak rencana penelitian ini baru disusun yakni semenjak bulan Maret tahun 2020. Penelitian terus berlangsung saat pengajuan proposal penelitian dinyatakan disetujui untuk dilanjutkan. Namun penelitian ini secara sah dilakukan semenjak diterimanya surat ijin penelitian dari lembaga, dan lewat berbagai prosedur administrasi maka penelitian dilakukan yakni sejak tanggal 20 Juli sampai dengan 20 Agustus tahun 2020.

Untuk mencapai validasi data penelitian dalam menyelesaikan permasalahn penelitian, maka keterkaitan data akan saling mendukung dan melengkapi, hasil penelitian akan valid dengan kolaborasi data yang saling mendukung untuk itu maka, berdasarkan kebutuhan terhadap ketersediaan beberapa data yang berkaitan dengan masalah penelitian, sehingga melibatkan pihak lain sebagai unsur yang tidak dapat dipisahkan dalam penelitian ini untuk menganalisis data. Dengan demikian pihak-pihak yang juga dilibatkan dalam menganalisis data dalam penelitian ini ialah keseluruhan Aparatur Pemerintah Desa Ilngei Kecamatan Tanimbar Selatan, dan BPMD Kabupaten Kepulauan Tanimbar.

Peran peneliti sangat diutamakan dalam penelitian kualitatif, karena dalam penelitian kualitatif peneliti sendirilah yang merupakan instrument utama dan secara langsung terlibat dalam kegiatan penelitian. Hal tersebut ditegaskan oleh Moleong, 2009:168 yang mengatakan bahwa "kegiatan penelitian terdiri dari perencanaan penelitian, pengumpulan data, analisis data, penafsiran data, dan pelaporan hasil penelitian serta peneliti merupakan segalanya dalam penelitian. Dengan demikian hal kehadiran menjadi faktor penentu keberhasilan penelitian maka dengan sungguh peneliti menyatakan bahwa peneliti sendiri yang berperan $100 \%$ atau dengan kata lain peneliti terlibat langsung dalam setiap kegiatan peneliti tanpa menggunakan bantuan dari orang lain untuk membantu peneliti dalam proses penelitian dan oleh karena peneliti sendiri yang berperan sebagai instrument penelitian, maka kehadiran peneliti tidak bisa kurang dari 1 (satu) hari dalam proses penelitian berdasarkan ketentuan waktu yang disusun oleh peneliti. (Moleong, dalam Sujarweni, V. Wiratna 2014).

Dalam penelitian ini penulis menggunakan dua jenis data untuk mengungkapan permasalahan penelitian mengenai manajemen pengelolaan dana desa dalam penanggulangan penyebaran virus COVID-19 di desa Ilngei Kecamatan Tanimbar Selatan Kabupan Kepulauan Tanimbar, diantaranya :

\section{Data Primer}

Data Primer adalah data yang diperoleh peneliti secara langsung dari pemberi informasi atau data langsung (sumber informasi atau informan) melalui 
wawancara dan lain sebagainya. Pemilihan informan dilakukan dengan teknik snowball sampling, atau pemilihan informan dengan sistem bola salju, mencari dan menemukkan informasi secara perlahan dan semakin berputar maka akan semakin besar informasi yang diperoleh, informan utama terdiri dari 7 informan dari pemerintah dan anggota masyarakat yang dianggap sangat menetahui tentang permasalahan penelitian antara lain:

1. Pejabat Desa Ilngei (Anditian E. Chayadi, S. IP)

2. Sekertaris Desa Ilngei (Stanislaus Setitit, S. IP)

3. Bandahara Desa (Cristian Lamere)

4. Kaur Pemerintahan (Yohanis Salembun)

5. Ketua BPD (Yohanis Batbual)

6. Sekertaris BPD (Bernarda Yabarmase)

7. Tokoh Pemuda ( Wilhelmus Batfutu)

2. Data Sekunder

Data Sekunder adalah data dalam bentuk tulisan berupa buku, jurna, dokumen yang sesuai dengan masalah yang dipakai sebagai data pendukung dalam menjelaskan permasalahan penelitian.

Menurut pendapat Moleong, dalam Sujarweni, V. Wiratna (2014). sumber data atau data kualitatif dapat berupa naratif, deskriptif, dalam kata-kata yang berasal dari mereka yang diteliti, dokumen pribadi, catatan lapangan, dokumen resmi dan lain sebagainya yang dapat memberikan informasi sesuai dengan masalah penelitian. Dengan berpegang pada pendapat tersebut, maka sumber data utama dalam penelitian ini adalah segala hal yang berasal dari ucapan atau perkataan, tingka laku atau perilaku dan atau tindakan yang tampak pada saat penelitian sedang berlangsung baik melalui wawancara, observasi dan lain sebagainya.
Menurut pendapat Milles dan Huberman (dalam Islami, 2001) mengatakan bahwa dalam penelitian kualitatif terdapat tiga alur kegiatan yang terjadi secara bersamaan dan tidak dapat dipisahkan yaitu : reduksi data, penyajian data, dan penarikan kesimpulan. Ketiga kegiatan tersebut berlangsung secara bersamaan dimana apabila dalam mereduksi data dan atau penyajian data dilakukan secara terus menerus atau diverifikasi secara berulang untuk menghindari peneliti dari subjektifitas dan sebagai langkah untuk menemukan data yang belum lengkap untuk dilengkapi atau ditelitilebih lanjut guna menyempurnakan kajian atau hasil penelitian.

Proses awal dalam menganalisis data yang telah diperoleh melalui observasi, wawancara dan dokumentasi direduksi, disingkatkan dan disusun lebih sistematis dengan memberikan kode dan memilah semua hasil penelitian yang diperoleh baik data baik primer maupun sekunder untuk dapat mempermudah dalam menetukan pokok penting yang akan dikaji mempermudah peneliti untuk mencari kembali data baru bila diperlukan, sebagai bentuk validasi data terhadap kajian hasil penelitian yang dilakukan.

Penyajian data atau display data merupakan proses lanjutan yang dilakukan dalam bentuk uraian singkat atau deskriptif atau penjelasan baik dalam bentuk tabel, bagan, skema, serta gambar yang dirancang dan telah tersusun secara sistematis, dalam suatu bentuk yang terpadu dan mudah dipahami. Penyajian data yang dilakukan pun tidak menutup kemungkinan untuk melakukan pengabilan data apabila kelengkapan validasi data masih belum valid.

Setelah berbagai data disusun dan diurutkan sesuai fokus penelitian maka data kemudian disimpulkan. Kesimpulan tersebut harus diverifikasi kembali selama penelitian berlangsung. Verifikasi data tidak hanya terjadi saat semua data dikumpulkan, melainkan verifikasi dapat dilakukan di awal penelitian, pertengahan hingga di akhir penelitian dengan tujuan untuk memperkuat hasil penelitian. 
Lokasi

Pintu Masuk 1. Terdapat Palang (Portal) yang terbentang (awal bulan Maret Desa Ilngei 2020, yang berfungsi sebagai sarana untuk dapat mengontrol keluar masuknya anggota masyarakat).

2. Pos penjagaan pada pintu masuk dengan petugas jaga yang terdiri dari masyarakta desa (relawan Pemuda desa).

3. Dalam penjagaan para relawan mengabaikan protokoler kesehatan dimana ada yang tidak mengguakan masker, selain itu ada juga masyarakat yang tidak menggunakan masker.

4. Kurangnya fasilitas air bersih sebagai penunjang pelaksanaan protokolkesehatan, sehingga ada masyarakat yang terpaksa diijinan masuk desa tanpa cuci tangan tepat saat air habis.

5. Belum ada kesadaran dari masyarakat desa Ilngei secara keseluruhan untuk mematuhi berbagai protokol kesehatan, ada yang tidak menggunakan masker namun masih bersih keras melawan saat berada di pintu masuk desa Ilngei.

6. Keterbatasan pengadaan cairan disinfektan untuk disemprot kepada masyarakat yang melintas di pintu masuk desa Ilngei.

7. Kelengkapan dari tenaga relawan di desa Ilngei masih terbatas.

Kantor Desa 1. Fasilitas penunjang protokol kesehatan sangat baik dan dipatuhi oleh setiap anggota masyarakat yang hendak berproses di kantor desa Ilngei.

2. Pegawai dan segenap struktur pemerintah desa Ilngei sampai dengan relawan yang bertugas di kantor desa secara keseluruhan telah mematuhi protokol kesehatan dengan baik.

3. Terdapat keterbatasan pengadaan cairan disinfektan untuk melakukan penyemprotan.

4. Masih dilakukan pemberian pelayanan kepada masyarakat, seperti pelayanan administrasi surat, berbagai keterangan dan lain sebagainya, tetapi pelayanan dilakukan dengan mematuhi protokol kesehatan.

5. Masyarakat yang datang dan di kantor desa untuk memperoleh pelyanan selalu dihimbau untuk terus mematuhi protokol kesehatan.

6. Masyarakat yang meminta pelayanan tidak akan dilayani apabila tidak mematuhi protokol kesehatan dengan memakai masker dan mencuci tangan serta tidak menjaga jarak

Dalam Desa 1. Masih ada masyarakat yang tidak menggunakan masker saat Ilngei melakukan aktifitas di dalam desa

2. Masyarakat dirumah masing-masing belum seluruhnya menyiapkan sarana penunjang sebagaiman protokol kesehatan yakni tidak menyiapkan air dan sabun di depan rumah,

3. Sikap masyarakat ada yang mendukung dan ada pula yang acu dan bahkan mengejek saat diberitahukan untuk memakai masker dan mencuci tangan serta tidak menjaga jarak.

4. Di depan sarana umum seperti kios-kios sembako masih ada yang tidak menyediakan sarana cuci tangan dengan baik.

5. Masih ada aktifitas masyarakat yang berlangsung tanpa mematuhi protokol kesehatan dengan berkumpul .

\section{Hasil}

Desa Ilngei adalah salah satu desa yang terletak di Kecamatan Tanimbar Selatan
Kabupaten Kepulauan Tanimbar, Desa Ilngei memiliki sistem pemerintahan yang dikepalai oleh seorang kepala desa, dan memiliki struktur adat yang masih kental dan selalu 
dipelihara secara baik. Dalam tatanan desa Ilngei terdapat tiga soa (Mata Rumah) yang terdiri dari Soa Olinger, Soa Maklarembun, Soa Watarembun.

Masing-masing soa memiliki hak dan kewajiban yang sama dalam kehidupan bermasyarakat, dengan menjunjung adat istiadat Duan Lolat. Selain itu desa Ilngei Kecamatan Tanimbar Selatan memiliki jumlah penduduk yang tersebar dalam desa. Penduduk desa Ilngei, Kecamatan Tanimbar Salatan Kabupaten Kepulauan Tanimbar masyarakat desa Ilngei yang berjenis kelamin laki-laki berjumlah 660 deng persentasi 50,34\% dan masyarakat desa Ilngei yang berjenis kelamin perempuan berjumlah 651 dengan persentasi 49,66.\% sehingga total jumlah penduduk masyarakat desa Ilngei adalah 1311 jiwa.

Desa Ilngei kecamatan Tanimbar Selatan Kabupaten Kepulauan Tanimbar dipimpin oleh kepala desa dan dalam melaksanakan tanggung jawab pemerintahan kepala desa dibantu oleh perangkat desa lainnya yakni Sekertaris Desa, Bendahara, dan Kepala-kepala Urusan (Kaur Pembangunan, Kaur Pemerintahan dll), RT dan RW dan juga Badan Permusyawaratan Desa (BPD). Dalam desa Ilngei ada juga tokoh adat, tokoh pemuda dan tokoh agama yang turut berperan dan manjadi bagian dalam penyelenggaraan pemerintah desa di desa Ilngei Kecamatan Tanimbar Selatan Kabupaten Kepuluan Tanimbar. Dalam penyelengaraan pemerintahan di desa Ilngei Kecamatan Tanimbar Selatan, Kepala desa dan Badan Permusyawaratan Desa (BPD) tidak memiliki garis perintah melainkkan garis koordinasi. Struktur pemerintahan desa Ilngei yang tersusun sistematis.

Tabel 1: Data Mentah.

Dalam penelitian yang dilakukan oleh peneliti di desa Ilngei Kecamatan Tanimbar Selatan Kabupaten Kepulauan Tanimbar yang dilakukan sejak tanggal 20 Juli sampai dengan 20 Agustus tahun 2020 proses pengumpulan data dilakukan dengan menggunakan teknik pengumpulan data melalui observasi, wawancara, studi dokumen dan studi kepustakaan. Dari proses pengumpulan data tersebut diperoleh data-data berupa data mentah hasil observasi dan data mentah hasil wawancara yang dapat dijabarkan dalam uraian berikut.

Dari hasil observasi tersebut ditemukan adanya berbagai hambatan yang benar-benar tidak sesuai dengan anjuran protokol kesehatan, mulai dari penyediaan sarana penunjang, sampai pada sikap masyarakat yang menganggap remeh dan acu terhadap berbagai anjuran yang diberikan. Dengan memperhatikan berbagai gejala dari hasil observasi tersebut, maka akan sulit dilakukan pencegahan dan penanggulangan Covid-19 bila tidak adanya kerja sama, pengertian dan kepatuhan masyarakat terhadap protokol kesehatan, justru sebaliknya masyarakat akan mudah terjangkit Covid-19.

Sesuai dengan hasil wawancara yang dilakukan terhadap beberapa informan, diketahui bahwa keseluruhan jumlah anggaran yang dikucurkan oleh pemerintah pusat dalam rangka penanggulangan penyebaran COVID-19 di desa Ilngei Kecamatan Tanimbar Selatan sebesar Rp. 558.772.500.

Da lam perencanaan dana penaggulangan COVID-19 di desa Ilngei, proses perencanaan dilakukan secara bersama atau dengan musyawarah bersama pemerintah dan masyarakat desa ilngei. Dalam proses perencanaan juga mengakomodir seluruh kebutuhan dan aspirasi masyarakat secara adil. Mekanisme proses perencanaan terdiri dari :

1. Muryawara bersama masyarakat yang dilakukan dengan mengakomodir keterwakilan masyarakat melalui ketuaketua RT.

2. Muryawara tidak dapat dilakukan dengan melibatkan seluruh masyarakat, karena pertimbangan protokol kesehatan yang menghindari kerumunan.

3. Proses perencanaan dilakukan bersama oleh pemerintah desa dengan keterwalilan masyarakat melalui ketuaketua RT. 
4. Pemerintah desa memimpin jalannya musyawarah, dan ketua-ketua RT berpartisipasi membahas kebijakan.

5. Dalam musyawarah pemerintah desa Ilngei lebih dominan dibanding dengan ketua-ketua RT.

6. Ketua-ketua RT belum mampu mengakomodir seluruh kebutuhan masyarakat desa Ilngei lewat kebijakan yang dikeluarkan, sehingga menimbulkan kekecewaan apa lagi terkait dengan keberadaan portal (palang) yang bukan hanya menjadi pintu masuk desa Ilngei tetapi juga pintu masuk bagi desa Wowonda.

Proses perencanaan berjalan dengan baik meskipun terjadi perdebatan tetapi atas kesepakatan bersama yang dibanguan dengan musyawarah maka mampu menghasilkan kebijakan-kebijakan yang mengakomodir aspirasi masyarakat desa walaupun dalam keterbatasan anggaran yang tersedia.

Dalam proses perencanaan penanggulangan penyebaran COVID-19 di desa Ilngei Kecamatan Tanimbar yang dilakukan dengan berbagai keterbatasan dan keterwakilan yang juga terbatas mengingat kondisi desa yang mengutamakan pematuhan terhadap protokol kesehatan, maka hasil perencanaan yang diperoleh antara lain :

1. Perlu pengadaan alat-alat pendukung seperti masker, vitamin, cairan disinvektan untuk penyemprotan, sabun cuci tangan, termoscan, alat pelindung tubuh dan lainnya.

2. Masyarakat diberikan bantuan langsung tunai (BLT) sesuai kriteria penerima bantuan dengan adil.

3. Masyarakat diberikan bantuan sembako untuk membantu pemenuhan kebutuhan makan dan lain sebagainya selama masa awal pandemi karena tidak diperbolehkan untuk keluar rumah.

4. Perlu untuk membuat palang agar lebih mudah mengontrol keluar masuknya masyarakat yang dapat membantu mendeteksi lebih awal untuk dilakukan karantina.
5. Menyediakan sarana cuci tangan dengan kelengkapan cuci tangan di pintu masuk dan tempat-tempat umum di dalam desa Ilngei.

6. Meningkatkan penjagaan untuk mengontrol secara menyeluruh masyarakat teristimewa pendatang untuk cepat melakukan karaentina.

7. Pemberlakukan karantina bagi masyarakat yang baru keluar daerah secar adil.

8. Membangun hubungan kerja sama dengan pihak kesehatan untuk melakukan sosialisasi protokol kesehatan, melayani pelayanan penanggulangan gejala Covid-19 sejak dini

9. Membentuk tim relawan Covid-19.

10. Menghumbau masyarakat untuk mematuhi protokol kesehatan untuk meminimalisir penyebaran Covid-19.

Hasil perencanaan ini kemudian ditindaklanjuti oleh pemerintah desa Ilngei walaupun dalam pelaksanaannya masih saja ditemukan adanya masyarakat yang bersikap acu, tidak peduli bahkan mengabaikan himbauan yang disampaikan namun hasil perencanaan telah dilaksanakan dengan baik.

Dari keseluruhan dapat hasil penelitian yang dilakukan di desa Ilngei, Kecamatan Tanimbar Selatan, dapat dijabarkan penjelasan data mentah hasil wawancara yang dilakukan terhadap 7 (tujuh) informan diluar informan lainnya. Hasil penelitian membuktikan bahwa ada sejumlah dana yang dikucurkan ke desa Ilngei untuk penganggulangan penyebaran Covid-19. Pemerintah desa Ilngei Kecamatan Tanimbar Selatan menggunakan dana tersebut dalam bentuk kebijakan-kebijakan pemberian Bantuan Langsung Tunai, Pembagian Masker Gratis bagi masyarakat, pembagian sembako, penadaan berbagai peralatan kesehatan penganggulangan penyebaran Covid-19 yakni, cairan disinfektan, termoscan, pelindung diri dan lain sebagainya. Pemerintah juga telah melakukan berbagai sosialisasi terkait V penganggulangan penyebaran Covid-19 akan tetapi ada juga masyarakat yang bersikap acu 
bahkan meremehkan, atau mengejek masyarakat dan pemerintah. Selain itu masyarakat juga berpemahaman bahwa pemberlakuan portal (palang) pada jalan juga merupakan salah satu kebijakan sesuai denga protokol kesehatan dalam penganggulangan penyebaran Covid-19.

Keberadaan portal (palang) dianggap sebagai suatu kebijakan yang kurang tepat karena keberadaannya tepat di jalan masuk desa Ilngei tetapi juga jalan masuk desa Wowonda. Selain itu para relawan dengan keterbatasan sarana pelindung diri dan sarana air bersih tetap melakukan tugasnya akan tetapi para relawan pun tidak dapat menghindari kerumunan yang terjadi di pos penjagaan pada pintu masuk desa. Dengan demikian maka seluruh kebijakan dalam penganggulangan penyebaran Covid-19 di desa Ilngei perlu untuk terus memperhatikan protokol kesehatan tetapi juga merencanakan pengelolaan, penggunaan dan pertanggung jawaban dana Covid-19 secara akuntabel.

Dalam pengelolaan dana desa secara khusus dana desa dalam penanggulangan penyebaran Covid-19 di desa tentunya dilakukan berdasarkan sistem pengelolaan yang ditentapkan oleh pemerintah pusat mulai dari mekanismen perencanaan, penganggaran, pelaksanaan, penatausahaan, pelaporan, sampai pada pertanggungjawaban penggunaan anggaran yang menjadi siklus tetap terhadap pengelolaan anggaran. Dari keseluruhan mekanismen tersebut, benar diakui bahwa sistem pengelolaan dana desa dalam penanggulangan penyebaran virus Covid-19 belum sepenuhnya terlaksanan sesuai dengan mekanisme penganggaran yakni selama 1 tahun terhitung tanggal 1 Januari sampai 31 Desember tahun berjalan, akan tetapi sistem pengelolaan dana desa dalam penanggulangan penyebaran virus Covid-19 di desa Ilngei berfokus pada perencanaan yang telah ditetapkan selama 1 tahun.

Perencanaan pengelolaan dan desa dilakukan dengan meknisme pengganggaran yang harus dilaksanakan selama periode 1 tahun terhitung tanggal 1 Januari sampai 31
Desember tahun berjalan dalam bentuk Rencana Anggaran Belanja tahunan. Rencana Anggaran Belanja dibahas bersama oleh pemerintah dan masyarakat sesuai dengan mekanisme pengelolaan anggaran dana desa sebagaimana dalam petunjuk pelaksanaan bimbingan dan konsultasi pengelolaan keuangan desa yang ditentapkan oleh Badan Pengawasan Keuangan dan Pembangunan tahun 2015. Lewat perencanaan sampai pada pertanggungjawaban sehingga pengelolaan dana desa dapa benar-benar membantu masyarakat secar khusus dalm rangka penanggulangan penyebaran virus Covid-19 di desa Ilngei.

Perencanaan merupakan salah satu fungsi dari manajemen atau pengelolaan termasuk pengelolaan komunikasi, baik ditinjau dari segi proses, bentuk maupun komponen-komponen atau unsur-unsur. Dari sudut proses, pengelolaan mencakup unsurunsur dalam manajemen, dan secara lengkap unsur-unsur tersebut terdiri dari perencanaan; pengorganisasian; pelaksanaan, pengkomunikasian, monitoring atau pengawasan dan penilaian. Perencanaan merupakan proses karya yang berkesinambungan sampai pada tahap pelaksanaan dan bahkan sampai pada tahap evaluasi. Dalam proses perencanaan, Seorang perencana selalu berusaha mengorganisasikan sumber-sumber atau seluruh sumber daya yang dimiliki termasuk keuangan, selain itu proses perencanaan melibatkan berbagai unsur di antaranya masyarakat, pemerintah dan stekholder lainnya. Menurut Harold Koontz dalam Nina Winangsih Syam (2015:41) mengatakan bahwa proses perencanaan bertujuan menentukan tujuan, menetapkan kaidah kemungkinan serta mencari dan menyelidiki berbagai kemungkinan rangkaian tindakan yang akan diambil, meramalkan kemungkinan dari sisi konseptual dan realitas, penilaian terhadap tiap kemungkinan dengan pertimbangan untung keunggulan dan kelemahan serta sampai pada penentuan dan pengambilan keputusan. Perencanaan pun harus mengantisipasi perubahan jika sewaktu- 
waktu dapat terjadi, sehingga penilaian terhadap kemungkinan tersebut sangat sulit untuk dilakukan. Keterlibatan masyarakat pun perlu untuk mampu mengakomodir kebutuhan tanpa mengabaikan keadilan dan asas kebersamaan.

Sesuai dengan konsep tersebut maka betapa pentingnya proses perencanaan yang didalamnya membahas, meramalkan, mengkaji mempertimbangkan dan menentukan sampai pada menetapkan program atau kegiatan untuk dilaksanakan. Perencanaan juga harus melibatkan masyarakat, pemerintah dan stekholder lainnya, namun yang terjadi di desa Ilngei justru sebaliknya. Perencanaan pengelolaan dana desa dalam penanggulangan penyebaran virus Covid-19 di desa Ilngei sama sekali bertentangan dengan kaidah konseptual perencanaan. Berdasarkan hasil observasi dan wawancara yang dilakukan ditemukan bahwa perencanaan pengelolaan dana desa dalam penanggulangan penyebaran virus Covid-19 di desa Ilngei ada banyak proses yang mengabaikan kaidah perencanaan diantaranya :

1. Perencanaan pengelolaan dana desa dalam penanggulangan penyebaran virus Covid-19 di desa Ilngei tidak transparansi;

2. Perencanaan lebih didominasi oleh pemerintah desa Ilngei;

3. Perencanaan hanya melibatkan keterwakilan masyarakat lewat RT/RW sedangkan masyarakat lainnya tidak dilibatkan;

4. Perencanaan dilakukan tanpa memperhatikan d a n mempertimbangkan keadaan ril desa, dimana saat awal penyebaran di bulan Februari sampai dengan Mei virus Covid-19 yang belum memakan korban, penjagaan begitu ketat, portal (palang) dijaga, penyediaan sarana cucu tangan, penyemprotan disinvektan, banyak himbauan dan lain sebagainya, sedanggkan saat ini di bakhir Oktober sampai dengan 15 Desember 2020 dengan jumlah angka positif Covid-19 mencapai 403 kasus positif justru tidak ada penjagaan portal (palang) rusak tidak difungsikan, masyarakat bebas tanpa masker dan lain sebagainya;

5. Hasil perencanaan hanya dilakukan di awal sedangkan pertengahan sampai akhir sama sekali tidak ada himbaunan dan lain sebagainya pada hal jumlah angka positif Covid-19 mencapai 403 kasus positif;

6. Masyarakat bahkan ada yang sama sekali tidak mengetahui adanya dana yang diberikan pemerintah pusat ke desa untuk penanggulangan penyebaran virus Covid-19 di desa Ilngei.

Dalam hal ini dengan konteks ril desa yang ada, maka proses perencanaan yang ada sama sekali tidak dilakukan sesuai dengan kaidah perencanaan yang sesunggukhnya. Namun apa yang hendak dilakukan saat ini dengan kondisi yang jumlah angka positif Covid-19 mencapai 403 kasus positif sudah tidak ada kebijakan yang dilakukan, sedangkan semua dana yang diterima tahap I telah terpakai habis, dengan demikian kebijakan dalam pengelolaan dana desa untuk penanggulangan penyebaran virus Covid-19 di desa Ilngei tidak tepat sasaran, masyarakat mempertanyakan kondisi yang terbalik (seng ada Covid-19 di desa Ilngei, masyarakat mempertanyakan kondidi ril yang justru terbalik (masyarakta dapa semprot, dapa marah kalo seng pake masker dan lain-lain sedangkan skarang yang positif banya tapi seng ada penjagaan lai) masyarakat selalu disemprot dengan cairan disinvektan sering dimarahi jika tidak menggunakan masker, dan lain sebagainya tetapi saat ini jumlah kasus positif semakin meningkat justru tidak ada penjagaan yang dilakukan. Inilah mkonteks ril yang terjadi akibat lemahnya proses perencanaan.

Menurut pendapat Nina Winangsih Syam (2015:43) mengatakan bahwa proses perencanaan harus melibatkan masyarakat, pemerintah dan stekholder lainnya. Pentingnya keterlibatan masyarakat, pemerintah dan stekholder dalam perencanaan akan sangat mempengaruhi kualitas hasil perencanaan yang dilakukan. Akan tetapi yang terjadi dalam 
pengelolaan dana desa untuk penanggulangan penyebaran virus Covid-19 di desa Ilngei justru tidak sesuai masyarakat hanya dilibatkan dengan keterwakilan dan dalam perencanaan melalui RT/RW dengan pertimbangan protokol kesehatan pada hal saat perencanaan dilakukan bulan Februari tahun 2020 jumlah kasus positif belum ada bahkan di Provinsi Maluku dan Kabupaten Kepulauan Tahimbar atau dengan kata lain desa Ilngei masih berada pada sona hijau. Tetapi perencanaan lebih dulu mengedepankan protokol kesehatan menghindari kerumunan sedangkan kondisi saat ini Provinsi Maluku dan Kabupaten Kepulauan Tahimbar ada pada Zona merah bahkan hitam justru mengabaikan protokol kesehatan. Hal ini membuktikan bahwa perencanaan yang dilakukan tanpa melibatkan masyarakat akan mengakibatkan kepentingan masyarakat tidak diakomodir dan hanya pemerintahlah yang mengendalikan perencanaan tersebut akibatnya dari sisi perencanaan masyarakat yang dirugikan.

Keterlibatan pemerintah desa dan masyarakat dalam proses perencanaan untuk pengelolaan dana desa dalam penanggulangan penyebaran virus Covid-19 di Desa Ilngei sama sekali mengabaikan kaidah perencanaan yang seharusnya melibatkan masyarakat, pemerintah dan stekholder. Seharusnya dalam perencanaan teristimewa terkait dengan pengelolaan dana desa untuk penanggulangan penyebaran virus Covid-19 di desa Ilngei masyarakat, pemerintah dan stekholder (misalnya petugas kesehatan dan lainnya) merupakan mitra yang saling melengkapi untuk memberikan kualitas perencanaan yang baik sesuai dengan kaidah peramalan dan pembahasan rencana anggaran berdasarkan kenyataan ril desa dan masyarakat harus dipandang sebagai objek perencanan.

Dalam Surat Edaran No. 8 Tahun 2020 tentang Desa Tanggap Covid-19 dan Penegasan Padat Karya Tunai Desa (PKTD) dan dalam Permenkeu No.50/PKM.07 tahun 2020 tentang perubahan kedua atas Permenkeu No.205/PKM.07/2019 tentang Pengelolaan Dana Desa memberikan penjelasan bahwa dalam Pengelolaan Dana Desa didasarkan pada asas transparansi, akuntabel dan menjunjung nilai-nilai kebersamaan. Namun dalam implementasi terhadap kedua aturan tersebut secara khusus dalam perencanaan sebagaimana dalam Permenkeu No.205/PKM.07/2019 tentang Pengelolaan Dana Desa, pemerintah desa Ilngei mengabaikan keberadaan masyarakat dan stekholder lainnya. Dalam SE No. 8 Tahun 2020 tentang Desa Tanggap Covid-19 dan Penegasan Padat Karya Tunai Desa (PKTD) menjelaskan bahwa Desa dan Relawan desa perlu membengun kerja sama dengan stekholder lainnya baik pihak rumah sakit sebagai rujukan maupun apotek dan lain sebagainya juga sama sekali diabaikan. Memang ada bentuk-bentuk kerja sama tetapi dalam kaitan dengan Surat Edaran No. 8 Tahun 2020 tentang Desa Tanggap Covid-19 dan Penegasan Padat Karya Tunai Desa (PKTD) belum terlaksanan dengan baik dan maksimal. Hal ini justru menimbulkan berbagai perspektif berbeda bahkan muncul kecurigaan namun masyarakat desa Ilngei hanya bersikap diam dengan alasan sama sekali tidak mengetahui tentang jumlah dan pengelolaan Dana Desa dalam Penanggulangan Penyebaran Virus Covid-19 di Desa Ilngei.

Sesuai dengan kenyataan yang telah ditampilkan dalam kajian penelitian berdasarkan hasil penelitian dan pendekatan konseptual yang telah dijabarkan maka lewat hasil penelitian ini maka penawaran solusi dari pendekatan konsep dan realitas yang dapat ditawarkan antara lain:

1. Proses perencanaan harus meliputi:

A. Pembahasan realitas masalah yang dihadapi saat ini

B. Mengkaji data dan fakta terkini terhadap masalah yang dihadapi

C. Meramalkan kemungkinan dengan mempertimbangkan keuntungan dan kerugian

D. Mempersiapkan kemungkinan lain yang dapat dilakukan bila terjadi perubahan rencana

E. Alternatif rencana harus dibahas bersama dengan menghadirkan berbagai stekholder yang sesuai 
dengan konteks masalah yang dihadapi

F. Pemerintah, masyarakat dan stekholder lainnya harus menjadi mitra dan masyarakat selalu menjadi objek kajian utama.

2. Pemerintah harus lebih terbuka dalam artian bahwa pemerintah transparan dan mengutamakan akuntabilitas perencanaan dan pelaksanaan.

3. Keterlibatan masyarat dan pemerintah dalam perencanaan harus dipandang sebagai rena untuk mengadu konsep demi kesejahrtaan bersama dan bukan rana beradu ketangkasan individu.

4. Pemerintah tidak boleh bersifat menentukan kebijakan, karena walaupun pemerintah ada bersama masyarakat tetapi belum tentu pemerintah memahami kebutuhan fundamental masyarakat, sehingga masyarakat perlu dilibatkan sehingga apa yang menjadi aspirasi dan kebutuhan masyarakat dapat dipenuhi untuk kesejaheraan.

Demikian solusi yang ditawarkan berdasarkan hasil penelitian dan pendekatan konseptual.

\section{Daftar Pustaka}

Bogdan \& Taylor. (1992). Introduction To Qualittative Research Methods A Phenomenological Approach To The Social Sciences. Terjemahan Arief Furchan. Surabaya: Usaha Nasional.

Handoko, T. H. (2001). Manajemen Personalia \& Sumberdaya Manusia. Edisi Kedua. Yogyakarta: BPFE Universitas Gadjah Mada.

Hasibuan. M. (2012). Manajemen Sumber Daya Manusia, edisi revisi. Jakarta: Bumi Perkasa.

Islamy. I. (2000). Prinsip - prinsip Perumusan Kebijaksanan Negara. Jakarta: Bumi Aksara.
Maleong. J. L. (2008). Metodologi Penelitian Kualitatif. Bandung: Remaja Rosdakarya Offset.

Malindar. B. (2020). Penyebab Ketimpangan Wilayah di Provinsi Maluku. Purwokerto:Pena Persada.

Miles, M.B. \& Huberman, A.M. (1984). Qualitative Data Analysis: A Sourcebook of New Methods. Beverly Hills CA: Sage Publications.

Nina, S. W. (2015). Posisi dan Perencanaan serta Pendekatan Humas. Bandung.

Daftar Pustaka Aturan

Kepres No. 07 Tahun 2020 tentang Pembentukan Gugus Tugas Percepatan Penanganan Corona Virus Disease (COVID-19)

Keputusan Presiden Republik Indonesia No. 11 Tahun 2020 Tentang Penetapan Kedaruratan Kesehatan Masyarakat Corona Virus Disease 2019 (Covid-19)

Peraturan Menteri Keuangan Republik Indonesia Nomor 43/PMK 05 tahun 2020 Tentang Mekanisme Pelaksanaan Anggaran Belanja Atas Beban Anggaran Pendapatan dan Belanja Negara dalam Penanganan Pandemi Corona Virus Disease 2019

Peraturan Pemerintah Pengganti Undangundang Republik Indonesia No.1 Tahun 2020 Tentang Kebijakan Keuangan Negara dan Stabilitas Sistem Keuangan Untuk Penanganan Pandemi Corona Virus Disease 2019 (covid-19) dan atau dalam Rangka Menghadapi Ancaman Yang Membahayakan Perekonomian Nasional dan atau Stabilitas Sistem Keuangan

Permendagri No. 113 tahun 2014 tentang Pengelolaan Dana Desa.

Surat Edaran No. 8 Tahun 20202020 Desa Tanggap Covid-19 dan Penegasan Padat Karya Tunai Desa (PKTD)

Undang-undang No: 32 tahun 2004 tentang Pemerintahan Daerah

Undang-undang No: 23 tahun 2014 tentang Pemerintahan Daerah 
Undang-undang Nomor 6 Tahun 2014 Tentang Desa

https://www.who.int/emergencies/diseases/ novelcoronavirus 2019 atauhttp:// infeksiemergingkemkes.go.id/category/ situasiinfeksiemerging/infocoronavirus/ http://jurnalfe.ustjogja.id 